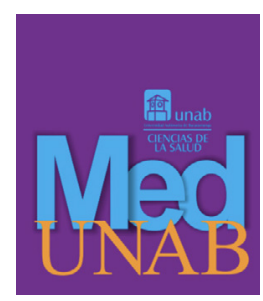

REVISTA DE LA FACULTAD

DE CIENCIAS DE LA SALUD

\title{
La práctica de la academia y la cirugía en tiempos del Covid-19
}

The practice of academia and surgery in times of Covid-19

\section{A prática da academia e da cirurgia nos tempos do Covid-19}

El 2020 será un año para recordar en todos los aspectos. Escribo estas letras con el fin de evaluar lo que ha sido el desarrollo de la profesión y lo que esperamos de ella durante estos tiempos. Iniciamos con gran optimismo el año 2020, con el desarrollo del programa de posgrado en cirugía general en nuestra universidad, el cual es un proyecto ambicioso que tiene la misión, desde el inicio, de lograr el posicionamiento como un programa abanderado, basado en la experiencia y el desarrollo de la ciencia que nos da el transitar en medios académicos por más de 30 años. Pero el verdadero motor para llevar a cabo este proyecto ha sido los mismos estudiantes, quienes hoy, agrupados bajo la modalidad de Semillero de Investigación, han generado diferentes compromisos académicos con los docentes y con la universidad. Además, la tecnología que nos aporta nuestro gran aliado en salud, la Fundación Oftalmológica de Santander Clínica Ardila Lülle - FOSCAL, así como el humanismo que nos ha acompañado durante todo este periodo, generará en nuestros usuarios una indescriptible sensación de seguridad y confianza en sus médicos.

Todas estas acciones van por buen camino, desde la etapa de diseño, la elaboración de protocolos y el cumplimiento con los trámites de rigor, así como con las metodologías propias de la educación en tiempos modernos.

No obstante, atravesamos un momento épico para la actual generación, representado por la presencia de un huésped no deseado: el Covid-19, que llegó sin ser invitado, y lo hizo para quedarse, no solo en la vida social, ni en la enfermedad como tal, sino también en el escenario de los quirófanos, ocasionando toda clase de cambios y revoluciones, hasta el punto de llegar a cambiar de forma radical la manera como vivimos en el ámbito de una sala de cirugía.

Sin embargo, no puede ser posible que un virus cambie las indicaciones de los procedimientos quirúrgicos, ni que altere la técnica que por muchas décadas hemos depurado. Está en nosotros defender nuestro más hermoso patrimonio: nuestra profesión. Es nuestra responsabilidad perpetuar la tradición de la técnica quirúrgica depurada, fina y con excelentes resultados. Hacer procedimientos quirúrgicos hoy, en medio de la pandemia, puede recibir muchos adjetivos: desde ser considerado como irresponsable, pasando por ser arriesgado, hasta ser visto como una quijotada, rompiendo paradigmas posiblemente creados por nosotros mismos. Hoy tenemos el conocimiento del comportamiento biológico del virus; tenemos 
experiencia, la mayoría importada y recibida gracias a la magia de las telecomunicaciones. Estos dos pilares del conocimiento nos permiten la adecuada utilización de las únicas armas que tenemos disponibles hoy para el adecuado desempeño de nuestra profesión. Me refiero a los elementos de protección personal. (EPP)

Ahora bien, estos EPP que nos están permitiendo trabajar, a su vez, nos están limitando el actuar como artesanos de cuerpo humano. La mayoría de estos EPP no fueron diseñados para ser utilizados en quirófanos: son adquiridos de la industria general, en donde no se ejecutan movimientos finos con exigencia de destreza y conocimiento. Hoy trabajamos con importantes limitaciones de movimiento, restricción del campo visual, alto índice de incomodidad y gran incertidumbre. Es necesario superar pronto estos escollos, con el fin de retornar a una actividad quirúrgica segura y confiable.

Aun así, nos hemos venido acostumbrando a las incomodidades; me preocupa mucho más la reincorporación de los estudiantes a las actividades de prácticas clínicas. Existen razones para prescindir de los estudiantes en los escenarios de práctica, pero también existen múltiples justificaciones para decir sí a la reincorporación de estas actividades. De igual forma que todas las actividades sociales, las actividades de docencia universitaria requieren un reinicio progresivo y seguro, hasta llegar a un desempeño óptimo, bajo las nuevas normas de convivencia social, respetando el uso de los EPP. Esto va a exigir la reubicación de espacios y el ajuste de tiempos.

No podemos, por ningún motivo, suspender la actividad académica, especialmente en una profesión tan importante para la sociedad como la nuestra. Estamos en una crisis de salud, y los expertos en estas crisis somos los profesionales del área. Todos nos matriculamos en esta profesión, y por esta razón debemos aprender, desde un momento temprano, a enfrentar estas situaciones difíciles, que en nuestra profesión se presentan con frecuencia.

Ante este panorama, la educación de posgrado en cirugía constituye un nuevo reto: crear escenarios de educación de posgrado en tiempo del Covid-19. Sabemos que no será fácil, pero también sabemos que lo llevaremos a un exitoso final, con el ofrecimiento de un programa de alta calidad académica, social y humana.

En estos momentos, la sociedad médica necesita un liderazgo que la conduzca a buen final. Un liderazgo soportado en el conocimiento actual, la epidemiología de la región y las herramientas con que contamos para tomar la decisión de reinventar la academia en cirugía.
Ese tipo de líder debe ser una persona arriesgada, con conocimientos, con espíritu emprendedor, acostumbrado a las dificultades y a superar obstáculos, a superar hasta sus propios miedos para sacar adelante su profesión. Una persona acostumbrada a enfrentar a la muerte en su día a día, en la gran mayoría de los casos, con éxito. En otras palabras, un cirujano.

Luis Ernesto López Gómez, MD., Esp.* Cirujano General y Oncológico Docente de Cátedra de Cirugía General. Facultad de Ciencias de la Salud UNAB Cirujano Centro de Cáncer, Clínica Carlos Ardila Lülle, Cirujano Staff Clínica Carlos Ardila Lülle, Cirujano Centro Elite. Unidad especializada en Sobrepeso y Obesidad. 